\section{Petters, Rates, and Antsiurers.}

Queries, answers, and communications relating to subjects to which special departments of the BRITISH MEDICAL JOURNAL are devoted will be found under their respective headings.

\section{QUERIES.}

A. E. has a patient, aged 70 , who suffers from dyspepsia and irritability of the bowels, following severe gastric influenza; irritability of the bowels, following severe gastric influenza; treated with urotropine, helmitol, and salol, which increases treated with urotropine, helmitol, and salol, which increases
the irritability of the bowel. Dilution with large quantities of water has been tried, and " A. E." asks what can be done of water has been tried, and

\section{ANSWERS.}

\section{TABE}

W. writes, in answer to "Fairlands," to suggest that the rectal pain in his case of tabes is probably due to intestinal stasis, and that the remedy is to secure the daily action of the bowels. "W." suggests the following: An hour before bedtime three or four teaspoonfuls of agar-agar (cut small) in a small cul of hot milk with a capsule containing $3 \mathrm{ss}$ of the liquid extract of cascara sagrada; a saline (as apenta) in a tumbler of hot water one hour before breakfast, and a simple normal saline enema to clear out the rectum at the time the bowels act. If these are not sufficient a 2-grain tablet of cascara with $3 j$ or $3 i j$ of white vaseline may be taken before teatime.

\section{LECCONYCHIA.}

TxaUis.-Our correspondent's son apparently suffers from leuconychia totalis, a well-known but rare abnormality of the nails. rThe appearance is due, according to Unna and most nails. The appearance is due, according to Unna and most other dermatologists who have had the opportunity of studying the disease, to the presence of air spaces in the nail. Such air spaces are caused by an irregular keratinization of the cells which form the substance of the nail. These shrink unduly and leave spaces which are filled with air. The etiology of the condition is obscure. In Unna's patient, a young man of 26 , it was congenital, but in most of the cases published the leuconychia seems to have been established after a local depression of the circulation with consequent coldness of the extremities. Even in Unna's case the patient had cold, somewhat cyanotic, hands. Some observers lay stress on the effects of slight traumatism in causing this curious change in the nails, but there must be in addition some predisposing factor. Leuconychia does not appear to have any special significance. As regards treatment, no satisfactory treatment is known, but, as the pathology of the satisfactory treatment is known, but, as the pathology of the condition appears to be similar to parakeratosis of the skin,
it is just possible that $x$ rays cautiously applied might be of it is just possil

Chewing Gum.

Dr. S. B. WALsh (School Medical Officer, Gillingham, Kent) writes: I agree with Dr. Gilchrist (p. 476) as to the probable beneficial effects of gum-chewing on the development of teeth and jaws. It is a practice in which I must plead occasional indulgence, and my experience satisfies me that it goes a long way towards supplying the cleansing and masticatory deficiencies of modern food. . We are told that the food of to-clay is too soft and pappy; that it lacks detergent properties : that it fails to encourage the proper secretion of saliva; that it leaves a residue round the teeth to ferment and corrode; and that the present lamentable condition of the national dental apparatus is the net result of the foregoing. Now, the oft-repeated mastication involved in gumcoing. Now, the oft-repeated mastication involved in gumchewing has the following certain effects. It develops the masseters and increases the blood supply of the dental arch and teeth; it flushes the mouth with acid-neutralizing saliva; it acts as an efficient cleansing agent, for the softened gum penetrates the smallest interstices between the teeth; it is mildly antiseptic and markedly deodorant; and, lastly, it is a fine antidote to excessive smoking. I am, of course, well aware that it is a habit which is calculated to irritate something that creates health must be accounted directly or derivatively beautiful, or nearly so-certainly much nearer so than carious malformed teeth. It is worthy of note that a monk who accompanied the Spanish conquerors to Mexico commented on the uniformly resular and beautiful teeth of the Aztec women, which he attributed to the habit, universal among them, of chewing "chicle," the basis of the presentday article. I have often thought that if gum could be popularized among children so as to replace a proportion of the sweets at present consumed, it would result in a of the sweets at present consumed, it would result in a generation.

TREATMENT OF TAENiA.

A. W.-Our correspondent should consult Sir Kingston Fowler's remarks on the treatment of taenia in the JoURNAL, vol. $i$, 1906, p. 841. The patient should be kept in bed under close observation; then male-fern will prove the most satisfactory remedy. Private and out-patient cases do not do so well as in-patients simply because they cannot be so thoroughly watched unless they have a private nurse. For two, three, beef-tea, one tin of Mason's essence, two rusks, and $4 \mathrm{oz}$. of port wine, whilst the patient takes 2 grains of extract of cascara sagrada three times daily. On the fourth day he should take, about 5 a.m., 1 oz. of haustus sennae co.; at 9 a.m., 15 minims of the extract of male-fern in a capsule, the close to be repeated at 9.15, 9.30, and 9.45. At 11 a.m. the haustus sennae must be repeated. If by $1 \mathrm{p} . \mathrm{m}$. the worm has not been passed and the head found, a second course of treatment with male-fern at intervals of a quarter of an hour must be carried out, to be followed in an hour by a purgative draught. If the head be not then found a third course of this traught. If the head be not then found a third course of this breaks at a distance of about $1 \frac{1}{2}$ in. from the head, and as breaks at a distance of about $1 \frac{1}{2}$ in. from the head, and as the fragment which remains is an exceedingly slender filament, the most careful scrutiny is absolutely needed. The
pan in which the motion is passed should be covered with pan in which the motion is passed should be covered with
black crape, to throw out in relief the fine white filament terminating in the head.

\section{DEATH OF THE EMPEROR NAPOLEON.}

M. D.-The officer acting as orderly officer at Longwood during the closing days of Napoleon's illness was Captain Crockat of the 20th Regiment, who was appointed to that position on April 14th, 1821. Captain Crockatt was entrusted with the official dispatches announcing the death of Napoleon, and on his arrival in England received his majority and a present of $\$ 500$. He became General Crockatt and died in 1879, at the advanced age of 87: So far as is known, he did not leave any papers relating to his connexion with Napoleon. Crockatt papers relating to his connexion with Napoleon. Crockatt who resigned his position of orderly officer on account of his who resigned his position of orderly officer on account of his treatment by Lowe and the commanding officer of the 20 th
Regiment. Napoleon had presented to Dr. Arnott a copy of Regiment. Napoleon had presented to Dr. Arnott a copy of and Lutyens was commissioned to send them to the regiment. and Lutyens was commissioned to send them to the regiment. But unfortunately the book was inscribed on the title page with the Imperial "N." and the words " L'Empereur Napoléon." might seduce the allegiance of the 20th Fout, the book was sent home to the Duke of York, Commander-in-Chief, for his decision. The Duke of York at once allowed the 20th Regiment to retain the book, saying that "Such a gift from Napoleon to a British regiment was most gratifying to him, and that the safe detention of Napoleon was sufficient testimony that the regiment had done its duty." The book is now in the archives of the 20th Regiment. (See History of 20th Regiment, by B. Smythe, M.V.O.)

Acute Pneumonia During Treatment with Arsenic.

Dr. George Pernet.(London, W.) writes, in reply to Dr. S. M. Hebblethwaite's letter in the JourNaL of March 8th, p. 529,

that a reference to the matter will be found in Kobert's exhaustive Lehrbuch der Intoxicationen, vol. ii, 1). 263 (Stuttgart: Enke. 1906).

LETTERS, NOTES, ETC.

In Praise of the Physician.

A YoRkshire G.P., who, for reasons of modesty, does not sign his name, writes: Apropos of your article "In Praise of the Physician," the following complimentary and touching sentence, addressed to me by an old Yorkshire farmer on his deathbed, may be of interest as an example of personal respeckit ye iver sin' I've knawn ye, an' I'll allus respec' ye efter I'm deid!

\section{Poetry a Disorder of the Intestines.}

C. writes: Two weeks ago I inserted in the JouRnal a query as to the origin of the above statement. My learned friend, Mr. C. W. F. Goss, of the Bishopsgate Institute; has kindly furnished me with what appears to be the solution. He points out that Carlyle in his Signs of the Times quotes from Pierre Jean Cabanis (1757-1808), physician to Mirabeau; as follows: "As the liver secrets bile so does the brain secret thought, but

Correction.

Is the article on The Knowledge of Tropical Diseases in 1813, published in the JounNal of March 1st, p. 455, there was an unfortunate misprint: the dose of laudanum used by Mr. Playfair in combination with half a drachm or a drachm of ipecacuanha was 30 to 60 drops.

GCALE OF CHARGES FOR ADYERTIBEMENTB IN THE BRITISH MEDICAL JOURNAL.

Eightlines and under Eightlinesand under A whole column

A page Än averäge line contains six words. $\begin{array}{rrrrr} & 2 & 8 . & d . \\ \ldots . & 0 & 4 & 0 \\ \ldots . & 0 & 0 & 6 \\ \ldots . & 2 & 13 & 4 \\ \ldots & 8 & 0 & 0\end{array}$ All remittances by Post Office Orders must be made pajable to the British Medical Association at the General Post Office, London. No responsibility will be accepted for any such remittance not so Advertisements shouid be delivered, addressed to the Manager, 429 . Strand, London, not later than the frist post on Wednesday morning preceding publication, and, if not paid for at the time, should be Note- It is against the rules of the Post Office to receive postes restantc letters addressed either in initials or numbers. 